\title{
Synthesis, Crystal Structure and Electrical Properties of a New Mixed Compound $\left(\mathrm{Na}_{0.71} \mathrm{Ag}_{0.29}\right)_{2} \mathrm{CoP}_{2} \mathrm{O}_{7}$
}

\author{
Riadh Marzouki ${ }^{1}$, Abderrahmen Guesmi ${ }^{1,2}$, Mohamed Faouzi Zid ${ }^{1 *}$, Ahmed Driss ${ }^{1}$ \\ ${ }^{1}$ Département de Chimie, Faculté des Sciences, Université Tunis El Manar, Tunis, Tunisie \\ ${ }^{2}$ Institut Préparatoire aux Etudes d'Ingénieur, Université Tunis El Manar, Tunis, Tunisie \\ Email: *faouzi.zid@fst.rnu.tn
}

Received October 9, 2012; revised November 15, 2012; accepted November 24, 2012

\begin{abstract}
A new cobalt diphosphate $\left(\mathrm{Na}_{0.71} \mathrm{Ag}_{0.29}\right)_{2} \mathrm{CoP}_{2} \mathrm{O}_{7}$, is synthesized by solid state reaction method and characterized by single-crystal X-ray diffraction. The title material crystallizes in the triclinic space group P-1 with a $=6.4170(3) \AA, b=$ 9.4510(2) $\AA, \mathrm{c}=10.9350(3) \AA, \alpha=115.240(2)^{\circ}, \beta=80.190(3)^{\circ}$ and $\gamma=106.810(2)^{\circ}$. The structure presents a centro-symmetrical clusters $\mathrm{Co}_{4} \mathrm{P}_{4} \mathrm{O}_{28}$ consists of two $\mathrm{Co}_{2} \mathrm{O}_{11}$ units and two $\mathrm{P}_{2} \mathrm{O}_{7}$ pyrophosphate groups. The junction between clusters is assured by two $\mathrm{P}_{2} \mathrm{O}_{7}$ groups to form a three-dimensional anionic framework having different interconnecting tunnels running along [100] and [010]. The former contains the $\mathrm{Na}^{+}$and $\mathrm{Ag}^{+}$cations. The conductivity measurements of $\left(\mathrm{Na}_{0.71} \mathrm{Ag}_{0.29}\right)_{2} \mathrm{CoP}_{2} \mathrm{O}_{7}$ are studied over a temperature interval from 783 to $903 \mathrm{~K}$ using the frequency response analyzer with $0.5 \mathrm{~V}$ amplitude signal over the range of $13 \mathrm{MHz}-5 \mathrm{~Hz}$.
\end{abstract}

Keywords: Diphosphate; X-Ray Diffraction; Anionic Framework; Tunnels; Conductivity

\section{Introduction}

Phosphate materials have vast applications in several domains as electric, pyroelectric, ferroelectric, magnetic, catalytic processes, state laser materials, etc. [1-7]. During the last years, there have been many studies of the compounds with general formula $\mathrm{A}_{2} \mathrm{BP}_{2} \mathrm{O}_{7}(\mathrm{~A}=$ monovalent cation, $\mathrm{B}=$ divalent ion) concerned the structural features and the electrical properties [8-12]. With regard to cobalt phases members, electrical studies were performed only for the tetragonal formula $\mathrm{Na}_{2} \mathrm{CoP}_{2} \mathrm{O}_{7}$ (bidimensional) [8]. It shows that the latter is an ionic conductor material. We have now prepared a new mixed diphosphate of the triclinic form. The synthesis, the structural study and the electrical properties of

$\left(\mathrm{Na}_{0.71} \mathrm{Ag}_{0.29}\right)_{2} \mathrm{CoP}_{2} \mathrm{O}_{7}$ (tridimensional) material are discussed here.

\section{Experimental}

\subsection{Synthesis of the Title Compound}

A mixture of high-purity reagents $\left(\mathrm{NaNO}_{3} / \mathrm{AgNO}_{3}\right.$, $\mathrm{Co}\left(\mathrm{NO}_{3}\right)_{2} \cdot 6 \mathrm{H}_{2} \mathrm{O}$ and $\left.\mathrm{NH}_{4} \mathrm{H}_{2} \mathrm{PO}_{4}\right)$ as polycrystalline form, with a Na:Ag:Co:P molar ratio of 1:1:1:2, is dissolved in deionised water to give a pink solution. After evaporation to dryness at $70^{\circ} \mathrm{C}$ in the oven, the residue, placed in porcelain crucible, is slowly annealed in air to $400^{\circ} \mathrm{C}$ for

"Corresponding author.
$24 \mathrm{~h}$, in order to eliminate volatile products. In a second step, it was progressively heated at $620^{\circ} \mathrm{C}$ for 5 days. The sample was slowly cooled at $5^{\circ} \mathrm{C} / 24 \mathrm{~h}$ to $580^{\circ} \mathrm{C}$ and finally quenched to room temperature. Purple single crystals of the title compound are extracted from the flux matrix with boiling water. A qualitative EDX (energydispersive X-ray spectroscopy) analysis (model: Philips XL 30) detected the presence of $\mathrm{Na}, \mathrm{Ag}, \mathrm{Co}, \mathrm{P}$ and oxygen elements. A polycrystalline powder of $\left(\mathrm{Na}_{0.71} \mathrm{Ag}_{0.29}\right)_{2}$ $\mathrm{CoP}_{2} \mathrm{O}_{7}$ was obtained by treating a stoichiometric mixture of the above reagents. The powder X-ray diffraction pattern was in agreement with single-crystal structure.

\subsection{Materials and Physical Measurements}

Impedance spectroscopy measurements were carried out in a Hewlet-Packar 4192-A automatic bridge monitored by a HP microcomputer. Impedance spectra were recorded in the $13 \mathrm{MHz}-5 \mathrm{~Hz}$ frequency range with $0.5 \mathrm{~V}$ alternative signal. Pellet was prepared by uniaxial shaping followed by isostatic pressing at $2.5 \mathrm{kbar}$ and sintering at $540^{\circ} \mathrm{C}$ for $2 \mathrm{~h}$ in air with $5 \mathrm{~K} \cdot \mathrm{min}^{-1}$ heating and cooling rates. The thickness and surface of pellet were about $0.356 \mathrm{~cm}$ and $0.454 \mathrm{~cm}^{2}$ having a geometric factor of $\mathrm{e} / \mathrm{S}=0.78 \mathrm{~cm}^{-1}$. Platinum electrodes were painted in the two faces of the pellet with a platinum paste to ensure good electric contacts and then painted pellet was carried out at steady-state temperatures in still air. 


\subsection{Crystal Structure Determination}

A suitable single crystal with dimensions $0.24 \times 0.21 \times$ $0.16 \mathrm{~mm}^{3}$ was chosen for the structure determination. The data were collected on an Enraf-Nonius CAD-4 diffractometer using the $\operatorname{MoK}_{\alpha}(\lambda=0.71069 \AA)$ radiation at room temperature. The structure was determinate by direct methods using SHELXS-97 program [13]. In the closest solution proposed by program, only some atoms of cobalt and phosphor were located. Using SHELXL-97 program [14], refinements followed by Fourier differences are necessary to find the positions of others atoms remaining in the lattice to an $\mathrm{R}$ factor of $2.55 \%$ for all reflections. The structure graphics were drawn with diamond 2.1 supplied by Crystal Impact [15]. A summary of crystallographic data, recording conditions and structure refinement results of the title compound is given in Table 1.

The atomic coordinates and isotropic thermal factors are presented in Table 2. Table 3 contains the main interatomic distances in coordination polyhedra of the studied structure.

\section{Results and Discussion}

The title compound is a new member of isostructural phases family including $\mathrm{Na}_{7} \mathrm{Mg}_{4,5}\left(\mathrm{P}_{2} \mathrm{O}_{7}\right)_{4}$ 2) [16], $\left.\mathrm{Na}_{2} \mathrm{CoP}_{2} \mathrm{O}_{7} 3\right)$ [17], $\left.\mathrm{Na}_{3.12} \mathrm{Fe}_{2.44}\left(\mathrm{P}_{2} \mathrm{O}_{7}\right)_{2} 4\right)$ [18], $\mathrm{Na}_{3.64}$ $\left.\mathrm{Mg}_{2.18}\left(\mathrm{P}_{2} \mathrm{O}_{7}\right)_{2} 5\right)$ and $\mathrm{Na}_{3.64} \mathrm{Ni}_{2.18}\left(\mathrm{P}_{2} \mathrm{O}_{7}\right)$ 6) [19]. This family of phases crystallizes in a centrosymmetric lattice, in

Table 1. Crystal data refinement results of $\left(\mathrm{Na}_{0.71} \mathrm{Ag}_{0.29}\right)_{2} \mathrm{CoP}_{2} \mathrm{O}_{7}$ compound.

\begin{tabular}{|c|c|}
\hline \multicolumn{2}{|c|}{ Crystal data } \\
\hline Crystal shape: Prism & Color: Purple \\
\hline Crystal system: Triclinic & Space group: $\mathrm{P}-1$ \\
\hline $\begin{array}{c}\text { Cell parameters: } \\
\mathrm{a}=6.417(3) \AA \alpha=115.24(2)^{\circ} \\
\mathrm{b}=9.451(2) \AA \beta=80.19(3)^{\circ} \\
\mathrm{c}=10.935(3) \AA \gamma=106.81(2)^{\circ}\end{array}$ & $\begin{array}{c}\mathrm{V}=573.4(3) \AA^{3} \\
\mathrm{Z}=2 \\
\rho=3.801 \mathrm{~g} \cdot \mathrm{cm}^{-3} \mathrm{~T}=298 \mathrm{~K}\end{array}$ \\
\hline \multicolumn{2}{|c|}{ Data collection } \\
\hline 4980 measured reflections & 2166 reflections with $\mathrm{I}>2 \sigma(\mathrm{I})$ \\
\hline 2491 independent reflections & $\mathrm{R}_{\mathrm{int}}=0.02$ \\
\hline $\mathrm{H}=-8 \rightarrow 8$ & $\mathrm{~T}_{\min }=0.554 ; \mathrm{T}_{\max }=0.402$ \\
\hline $\mathrm{K}=-12 \rightarrow 12$ & $\theta_{\max }=26.97^{\circ} ; \theta_{\min }=2.06^{\circ}$ \\
\hline $\mathrm{L}=-13 \rightarrow 13$ & Decay $=1 \%$ \\
\hline \multicolumn{2}{|c|}{ Refinement } \\
\hline $\mathrm{R}[\mathrm{I}>2 \sigma(\mathrm{I})]=0.0255$ & $\mathrm{wR}_{2}\left(\mathrm{~F}^{2}\right)=0.0618$ \\
\hline $\mathrm{S}=1.07$ & Extinction coefficient: 0.0031 (6) \\
\hline$\Delta \rho_{\max }=0.71 \mathrm{e} \cdot \AA^{-3}$ & $\Delta \rho_{\min }=-0.56 \mathrm{e} \cdot \AA^{-3}$ \\
\hline 258 parameters & 2491 reflections \\
\hline
\end{tabular}

Table 2. Atomic coordinates and isotropic thermal factors of $\left(\mathrm{Na}_{0.71} \mathrm{Ag}_{0.29}\right)_{2} \mathrm{CoP}_{2} \mathrm{O}_{7}$.

\begin{tabular}{cccccc}
\hline Atoms & $\mathbf{x}$ & $\mathbf{y}$ & $\mathbf{z}$ & $\mathbf{U}_{\text {iso }}{ }^{*}$ & Occupancy \\
\hline $\mathbf{C o 1}$ & $0.3545(7)$ & $0.26562(5)$ & $0.76417(4)$ & $0.00967(2)$ & 1 \\
$\mathbf{C o 2}$ & $0.2783(7)$ & $0.61021(5)$ & $0.71736(4)$ & $0.01031(2)$ & 1 \\
$\mathbf{P 1}$ & $0.4257(3)$ & $0.65654(1)$ & $0.95528(8)$ & $0.00855(8)$ & 1 \\
$\mathbf{P 2}$ & $0.2858(4)$ & $0.27129(1)$ & $0.46202(8)$ & $0.00982(8)$ & 1 \\
$\mathbf{P 3}$ & $0.1219(3)$ & $0.63778(1)$ & $0.18316(9)$ & $0.00952(8)$ & 1 \\
$\mathbf{P 4}$ & $-0.0770(4)$ & $0.10713(1)$ & $0.28674(9)$ & $0.01362(9)$ & 1 \\
$\mathbf{O 1}$ & $0.6880(4)$ & $0.2606(3)$ & $0.7245(2)$ & $0.0182(5)$ & 1 \\
$\mathbf{O 2}$ & $0.2116(5)$ & $0.4255(3)$ & $0.5341(3)$ & $0.0215(6)$ & 1 \\
$\mathbf{O 3}$ & $0.4444(4)$ & $0.5208(3)$ & $0.8156(2)$ & $0.0112(5)$ & 1 \\
$\mathbf{O 4}$ & $0.0304(4)$ & $0.2645(3)$ & $0.8112(3)$ & $0.0206(6)$ & 1 \\
$\mathbf{O 5}$ & $0.2278(4)$ & $0.5753(3)$ & $0.0322(2)$ & $0.0140(5)$ & 1 \\
$\mathbf{O 6}$ & $-0.0161(4)$ & $0.5167(3)$ & $0.7972(3)$ & $0.0195(6)$ & 1 \\
$\mathbf{O 7}$ & $0.9557(5)$ & $-0.0518(4)$ & $0.8485(3)$ & $0.0369(8)$ & 1 \\
$\mathbf{O 8}$ & $0.5668(4)$ & $0.7289(3)$ & $0.6619(3)$ & $0.0221(6)$ & 1 \\
$\mathbf{O 9}$ & $0.2841(4)$ & $0.0145(3)$ & $0.6998(3)$ & $0.0153(5)$ & 1 \\
$\mathbf{O 1 0}$ & $0.3788(4)$ & $0.2781(3)$ & $0.9609(2)$ & $0.0162(5)$ & 1 \\
$\mathbf{O 1 1}$ & $0.1141(5)$ & $0.7259(3)$ & $0.6656(4)$ & $0.0310(7)$ & 1 \\
$\mathbf{O 1 2}$ & $0.9249(4)$ & $0.8744(3)$ & $0.5989(3)$ & $0.0145(5)$ & 1 \\
$\mathbf{O 1 3}$ & $0.3769(4)$ & $0.2275(3)$ & $0.5562(2)$ & $0.0170(5)$ & 1 \\
$\mathbf{O 1 4}$ & $0.3543(4)$ & $0.7872(3)$ & $0.9368(3)$ & $0.0164(5)$ & 1 \\
$\mathbf{N a 1}$ & $0.024(2)$ & $0.2050(4)$ & $0.0244(2)$ & $0.019(3)$ & $0.899(2)$ \\
$\mathbf{A g 1}$ & $0.027(4)$ & $0.212(3)$ & $0.016(2)$ & $0.017(3)$ & $0.101(2)$ \\
$\mathbf{N a 2}$ & $0.592(3)$ & $0.0065(6)$ & $0.8113(5)$ & $0.0229(7)$ & $0.340(2)$ \\
$\mathbf{A g 2}$ & $0.5754(4)$ & $-0.0075(2)$ & $0.8338(3)$ & $0.0229(7)$ & $0.503(9)$ \\
$\mathbf{A g 3}$ & $0.6006(2)$ & $-0.0203(7)$ & $0.8560(7)$ & $0.0229(7)$ & $0.157(8)$ \\
$\mathbf{A g 4}$ & $0.7170(2)$ & $0.0533(1)$ & $0.54694(9)$ & $0.0492(5)$ & $0.313(2)$ \\
$\mathbf{N a 3}$ & $0.7170(2)$ & $0.0533(1)$ & $0.54694(9)$ & $0.0492(5)$ & $0.424(7)$ \\
$\mathbf{N a 4}$ & $1 / 2$ & 0 & $1 / 2$ & $0.043(2)$ & $0.526(2)$ \\
$\mathbf{N a 5}$ & $0.2060(2)$ & $0.5653(9)$ & $0.4081(7)$ & $0.0278(1)$ & $0.912(2)$ \\
$\mathbf{A g 5}$ & $0.2430(3)$ & $0.5330(2)$ & $0.3776(7)$ & $0.0390(3)$ & $0.088(2)$ \\
& & ${ }^{*} \mathbf{U}_{\dot{e} \mathbf{q}}=(\mathbf{1} / 3)$ & $\sum_{\mathbf{i}} \sum_{\mathbf{j}} \mathbf{U}^{\mathrm{ij}} \mathbf{a}_{\mathbf{i}}{ }^{*} \mathbf{a}_{\mathbf{j}}{ }^{*} \mathbf{a}_{\mathbf{i}} \cdot \mathbf{a}_{\mathbf{j}} \cdot$ & \\
\hline & & & & & \\
\hline
\end{tabular}

Table 3. Main interatomic distances $(\AA)$ in $\left(\mathrm{Na}_{0.71} \mathbf{A g}_{0.29}\right)_{2}$ $\mathrm{CoP}_{2} \mathrm{O}_{7}$ compound.

\begin{tabular}{|c|c|c|c|}
\hline \multicolumn{2}{|c|}{ Octahedron Co(1)O6 } & \multicolumn{2}{|c|}{ Octahedron $\mathrm{Co}(2) \mathrm{O6}$} \\
\hline $\mathrm{Co} 1-\mathrm{O} 4$ & $2.053(3)$ & $\mathrm{Co} 2-\mathrm{O} 11$ & $2.006(3)$ \\
\hline $\mathrm{Co} 1-\mathrm{O} 9$ & $2.096(2)$ & $\mathrm{Co} 2-\mathrm{O} 8$ & $2.012(3)$ \\
\hline $\mathrm{Co} 1-\mathrm{O} 1$ & $2.120(3)$ & $\mathrm{Co} 2-\mathrm{O} 2$ & $2.031(3)$ \\
\hline $\mathrm{Co} 1-\mathrm{O} 13$ & $2.132(3)$ & $\mathrm{Co} 2-\mathrm{O} 6$ & $2.060(3)$ \\
\hline $\mathrm{Co} 1-\mathrm{O} 10$ & $2.134(3)$ & $\mathrm{Co} 2-\mathrm{O} 3$ & $2.165(2)$ \\
\hline $\mathrm{Co} 1-\mathrm{O} 3$ & $2.149(2)$ & $\mathrm{Co} 2-\mathrm{O} 14$ & $2.302(3)$ \\
\hline \multicolumn{2}{|c|}{ Tetrahedron P(1)O4 } & \multicolumn{2}{|c|}{ Tetrahedron P(2)O4 } \\
\hline $\mathrm{P} 1-\mathrm{O} 10 \mathrm{i}$ & $1.502(3)$ & $\mathrm{P} 2-\mathrm{O} 2$ & $1.505(3)$ \\
\hline $\mathrm{P} 1-\mathrm{O} 14$ & $1.532(2)$ & $\mathrm{P} 2-\mathrm{O} 13$ & $1.510(2)$ \\
\hline $\mathrm{P} 1-\mathrm{O} 3$ & $1.532(2)$ & $\mathrm{P} 2-\mathrm{O} 8 \mathrm{iii}$ & $1.514(3)$ \\
\hline $\mathrm{P} 1-\mathrm{O} 5 \mathrm{ii}$ & $1.592(3)$ & $\mathrm{P} 2-\mathrm{O} 12 \mathrm{iii}$ & $1.617(3)$ \\
\hline \multicolumn{2}{|c|}{ Tetrahedron $\mathrm{P}(3) \mathrm{O} 4$} & \multicolumn{2}{|c|}{ Tetrahedron P(4)O4 } \\
\hline P3-O4iv & $1.506(2)$ & $\mathrm{P} 4-\mathrm{O} 7 \mathrm{v}$ & $1.500(3)$ \\
\hline P3-O6iv & $1.511(3)$ & P4-O11iv & $1.514(3)$ \\
\hline P3-O1iii & $1.531(3)$ & $\mathrm{P} 4-\mathrm{O} 9 \mathrm{vi}$ & $1.517(3)$ \\
\hline $\mathrm{P} 3-\mathrm{O} 5$ & $1.598(3)$ & P4-O12iii & $1.637(3)$ \\
\hline
\end{tabular}

Symmetry codes: (i): $-\mathrm{x}+1,-\mathrm{y}+1,-\mathrm{z}+2$; (ii): $\mathrm{x}, \mathrm{y}, \mathrm{z}+1$; (iii): $-\mathrm{x}+1,-\mathrm{y}+$ $1,-\mathrm{z}+1$; (iv): $-\mathrm{x},-\mathrm{y}+1,-\mathrm{z}+1 ;$ (v): $-\mathrm{x}+1,-\mathrm{y},-\mathrm{z}+1 ;$ (vi): $-\mathrm{x},-\mathrm{y},-\mathrm{z}+1$. 
the space group $\mathrm{P}-1$. The 3 structure is to claim to be not centrosymmetric (P1 GE). For $\mathrm{Na}_{2} \mathrm{CoP}_{2} \mathrm{O}_{7}$ material, we note the stoichiometry of the chemical composition. The report of the formula as determined from 3) $\mathrm{Na} / \mathrm{Co}=2$, which agrees with the results found in the structural study of the title compound $(\mathrm{Na}, \mathrm{Ag}) / \mathrm{Co}=2$.

The asymmetric unit in $\left(\mathrm{Na}_{0.71} \mathrm{Ag}_{0.29}\right)_{2} \mathrm{CoP}_{2} \mathrm{O}_{7}$ compound is shown in Figure 1. The structure is composed of two octahedrons sharing corner and forming $\mathrm{Co}_{2} \mathrm{O}_{11}$ group. The latter is linked on one side by edge with $\mathrm{P}_{2} \mathrm{O}_{7}$ group. On the other side, a second diphosphate is connected sharing corners with $\mathrm{Co}_{1} \mathrm{O}_{6}$ and $\mathrm{Co}_{2} \mathrm{O}_{6}$. The compensation of charge in the asymmetric unit is ensured by $\mathrm{Ag}^{+}$and $\mathrm{Na}^{+}$cations.

In the anionic framework, the $\mathrm{Co}_{2} \mathrm{O}_{11}$ octahedral groups are arranged in the $\left(\begin{array}{ll}1-1 & 0\end{array}\right)$ plane (Figure 2). The connection between two $\mathrm{Co}_{2} \mathrm{O}_{11}$ units and two diphosphate groups is assured by mixed bridges Col-O-P and sharing edges with $\mathrm{ColO}_{6}$ octahedra, to form the $\mathrm{Co}_{4} \mathrm{P}_{4} \mathrm{O}_{28}$ cluster (Figure 3).

Along the three directions of the cell, the junction between these clusters is provided by two diphosphates groups sharing a corner with the $\mathrm{CoO}_{6}$ octahedra thus forming a three-dimensional framework (Figure 4). However, the structure belongs to the dichromate family [20] which the conformation of this group is eclipsed.

The three-dimensional network shows the existence of two types of tunnels along [100] with hexagonal and decagonal sections (Figure 5(a)). A projection of the ani-

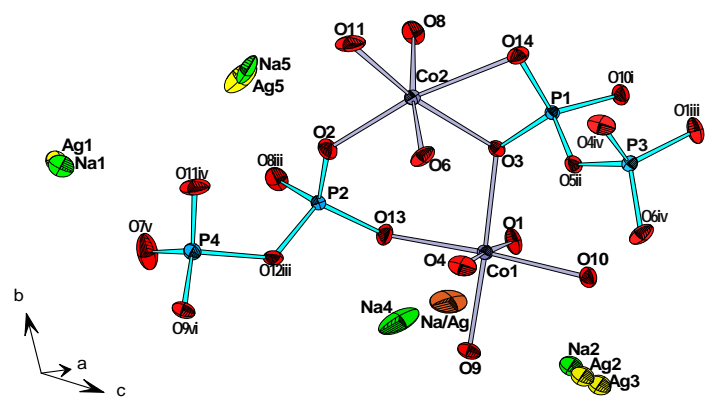

Figure 1. Asymmetric unit of $\left(\mathrm{Na}_{0.71} \mathrm{Ag}_{0.29}\right)_{2} \mathrm{CoP}_{2} \mathrm{O}_{7}$ compound.

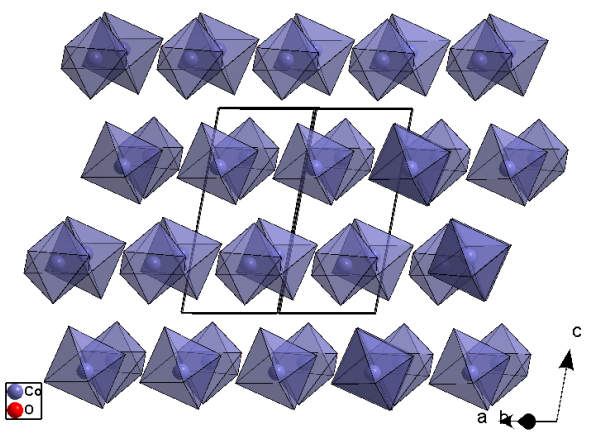

Figure 2. Octahedral representation of the structure showing the arrangement of $\mathrm{Co}_{2} \mathrm{O}_{11}$ groups in the (1-1 0 ) plane. onic framework in the $b$ direction is given in Figure 5(b).

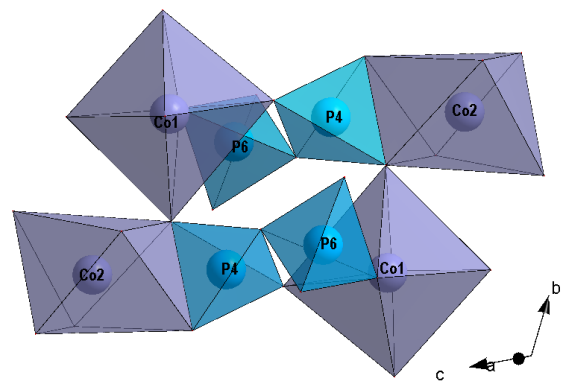

Figure 3. Projection of $\mathrm{Co}_{4} \mathrm{P}_{4} \mathrm{O}_{28}$ cluster of $\left(\mathrm{Na}_{0.71} \mathrm{Ag}_{0.29}\right)_{2}$ $\mathrm{CoP}_{2} \mathrm{O}_{7}$ viewed near the $[100]$ direction.

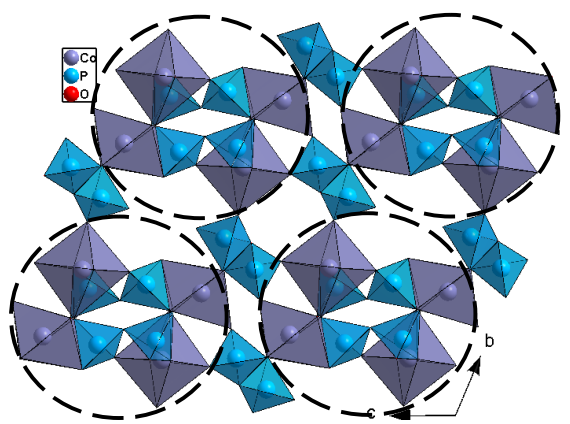

Figure 4. Junction between clusters ensured by the diphosphate groups in bc plane of $\left(\mathrm{Na}_{0.71} \mathrm{Ag}_{0.29}\right)_{2} \mathrm{CoP}_{2} \mathrm{O}_{7} \mathrm{com}$ pound.

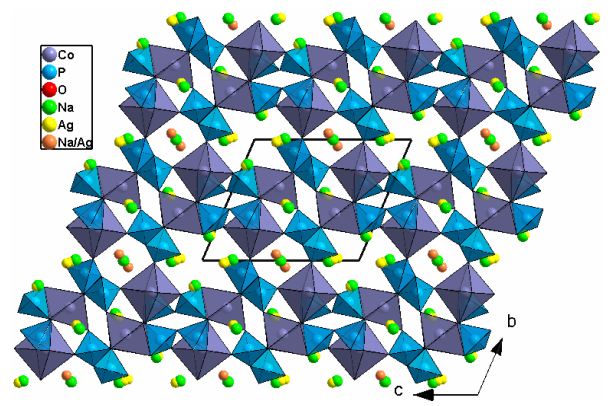

(a)

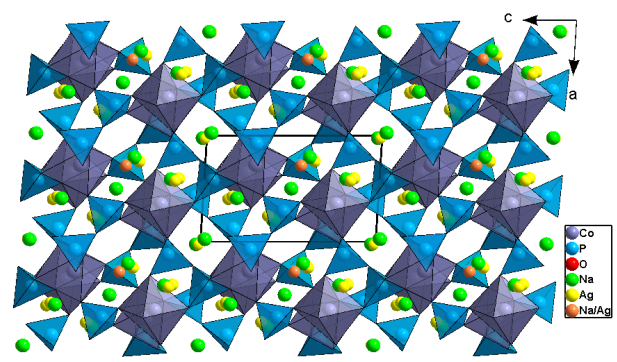

(b)

Figure 5(a). Projection of $\left(\mathrm{Na}_{0.71} \mathrm{Ag}_{0.29}\right)_{2} \mathrm{CoP}_{2} \mathrm{O}_{7}$ structure along [100] direction showing tunnels where monovalent cations are located; (b): Projection of $\left(\mathrm{Na}_{0.71} \mathrm{Ag}_{0.29}\right)_{2} \mathrm{CoP}_{2} \mathrm{O}_{7}$ structure along $[010]$ direction showing the windows and the channels. 
It shows the presence of channels and quadrilateral windows along this direction. The monovalent cations are located in these tunnels.

The electrical properties of the title compound are investigated using complex impedance spectroscopy (CIS). The electrical data exploitation was realized in the thermal range 783 - $903 \mathrm{~K}$. The Nyquist plots at different temperature for $\left(\mathrm{Na}_{0.71} \mathrm{Ag}_{0.29}\right)_{2} \mathrm{CoP}_{2} \mathrm{O}_{7}$ material are shown in Figure 6. We have used the Zview software [21] to fit these curves. The bulk ohmic resistance relative to each experimental temperature is deduced from complex impedance diagrams. It is the intercept $\mathrm{ZO}$ on the real axis of the zero phase angle extrapolation of the highest frequency curve. The resistivity parameters $\mathrm{R}$ for this compound vary with temperature according to Arrheniustype laws. The $\left(\mathrm{Na}_{0.71} \mathrm{Ag}_{0.29}\right)_{2} \mathrm{CoP}_{2} \mathrm{O}_{7}$ impedance diagrams show only one typical semicircle arc with a spike at lower frequencies. The best fit is obtained when we used an equivalent circuit composed of a resistor, $\mathrm{R}$ connected in parallel with a constant phase element, CPE (Figure 7) [22]. No additional blocking effect could be evidenced at lower frequencies $(f \leq 20 \mathrm{~Hz}$ ). Values of electric parameters calculated for $\left(\mathrm{Na}_{0.71} \mathrm{Ag}_{0.29}\right)_{2} \mathrm{CoP}_{2} \mathrm{O}_{7}$ compound, at different temperatures, after fitting are illustrated in Table 4.

A linear plots of $\log \left(\sigma \mathrm{T}\left(\mathrm{S} . \mathrm{K} \cdot \mathrm{cm}^{-1}\right)\right)$ vs. $10^{3} / \mathrm{T}\left(\mathrm{K}^{-1}\right)$ is represented in Figure 8. The conductivity value $\sigma$ at 683 $\mathrm{K}$ is $2.61 \times 10^{-7} \mathrm{~S} \cdot \mathrm{cm}^{-1}$ and the activation energy deduced from the slope is $\mathrm{Ea}=1.368 \mathrm{eV}$ (Figure 8). Compared to the activation energies observed in $\mathrm{Na}_{2} \mathrm{CoP}_{2} \mathrm{O}_{7}$ material $\left(\mathrm{E}_{\mathrm{a}}=0.63 \mathrm{eV}\right)[8]$, in $\mathrm{NaAgZnP}_{2} \mathrm{O}_{7}\left(\mathrm{E}_{\mathrm{a}}=0.76\right.$ $\mathrm{eV})$ [23], in $\mathrm{Na}_{2} \mathrm{PbP}_{2} \mathrm{O}_{7}\left(\mathrm{E}_{\mathrm{a}}=0.90 \mathrm{eV}\right)$ [24] and

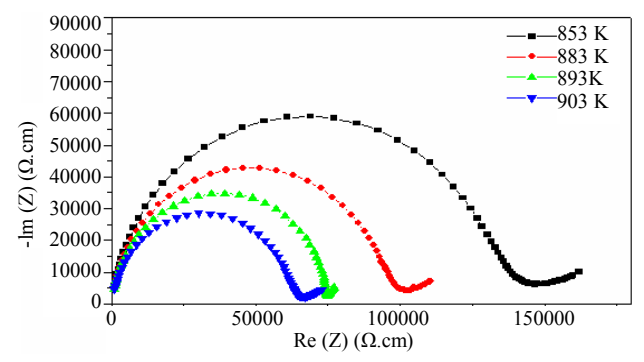

Figure 6. Impedance spectra recorded on $\left(\mathrm{Na}_{0.71} \mathbf{A g}_{0.29}\right)_{2}$ $\mathrm{CoP}_{2} \mathrm{O}_{7}$ sample over the temperature ranges $853-903 \mathrm{~K}$.

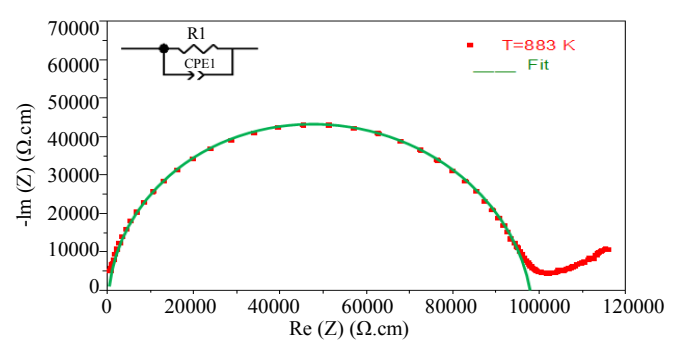

Figure 7. Impedance spectra recorded on $\left(\mathrm{Na}_{0.71} \mathrm{Ag}_{0.29}\right)_{2}$ $\mathrm{CoP}_{2} \mathrm{O}_{7}$ sample over the temperature ranges 853 - $903 \mathrm{~K}$.
$\mathrm{Ag}_{2} \mathrm{PbP}_{2} \mathrm{O}_{7}\left(\mathrm{E}_{\mathrm{a}}=0.78 \mathrm{eV}\right)[25],\left(\mathrm{Na}_{0.71} \mathrm{Ag}_{0.29}\right)_{2} \mathrm{CoP}_{2} \mathrm{O}_{7}$ exhibit a low electric conductivity.

Data from the structural study of $\left(\mathrm{Na}_{0.71} \mathrm{Ag}_{0.29}\right)_{2} \mathrm{CoP}_{2} \mathrm{O}_{7}$ compound show that the monovalent cations are located in 3 types of tunnels whose section dimensions are illustrated in Figure 9. In the [100] direction, the $\mathrm{Na}^{+}$and $(\mathrm{Na} / \mathrm{Ag})^{+}$ions are located in a tunnel of hexagonal section with maximum section equal to 4.671 (6) $\AA$ (Figure 9(a)). The other tunnel contains the $\mathrm{Na}^{+}$and $\mathrm{Ag}^{+}$ions. The smaller sections of these tunnels in this direction are 3.699 (3) $\AA$ and 3.460 (5) $\AA$ which are inferior to $2\left(\mathrm{r}_{\mathrm{o}}{ }^{2-}\right.$ $\left.+\mathrm{r}_{\mathrm{Na}}{ }^{+}\right)=5.18 \AA$ and $2\left(\mathrm{r}_{\mathrm{o}}{ }^{2-}+\mathrm{r}_{\mathrm{Ag}}{ }^{+}\right)=5.40 \AA$ according to Shannon [26]. Furthermore, in the $b$ direction, the tunnel of hexagonal section (Figure 9(b)) contains a bottleneck of small width equal to 2.917 (3) $\AA$. It is smaller also than twice the sum of ray $\mathrm{r}_{\mathrm{o}}{ }^{2-}=1.42 \AA$ and $\mathrm{r}_{\mathrm{Na}}{ }^{+}=1.18 \AA$ $\left(5.18 \AA\right.$ ) for $\mathrm{Na}^{+}$and $2\left(\mathrm{r}_{\mathrm{o}}{ }^{2-}+\mathrm{r}_{\mathrm{Ag}}{ }^{+}\right)=5.40 \AA$ for $\mathrm{Ag}^{+} \mathrm{ac}-$ cording Shannon [26]. These geometric factors are causing a low mobility of the cations $(\mathrm{Ea}>1 \mathrm{eV})$.

\section{Conclusion}

In the summary, in this work we have synthesized a new diphosphate compound of composition

$\left(\mathrm{Na}_{0.71} \mathrm{Ag}_{0.29}\right)_{2} \mathrm{CoP}_{2} \mathrm{O}_{7}$ by solid state reaction. This material was characterized by $\mathrm{X}$-ray diffraction. The sample crystallized in triclinic symmetry with $\mathrm{P}-1$ space group $(Z=2)$

Table 4. Electrical values of the equivalent circuit parameters calculated for $\left(\mathrm{Na}_{0.71} \mathrm{Ag}_{0.29}\right)_{2} \mathrm{CoP}_{2} \mathrm{O}_{7}$ sample at different temperatures.

\begin{tabular}{ccccc}
\hline $\mathbf{T}(\mathbf{K})$ & $\mathbf{R}\left(\times \mathbf{1 0} \mathbf{5}^{\mathbf{5}} \mathbf{\Omega} \cdot \mathbf{c m}\right)$ & $\mathbf{C}\left(\times \mathbf{1 0}^{-\mathbf{1 2}} \mathbf{F}\right)$ & $\mathbf{P}$ & $\boldsymbol{\sigma}\left(\times \mathbf{1 0} \mathbf{5}^{\mathbf{S}} \mathbf{\mathbf { c m } ^ { - 1 }}\right)$ \\
\hline 783 & 6.51 & 8.0 & 0.9 & 0.12 \\
813 & 3.09 & 8.7 & 0.9 & 0.25 \\
853 & 1.08 & 10.9 & 0.9 & 0.73 \\
883 & 0.77 & 11.8 & 0.9 & 1.02 \\
893 & 0.59 & 8.4 & 0.9 & 1.33 \\
903 & 0.50 & 9.9 & 0.9 & 1.57 \\
\hline
\end{tabular}

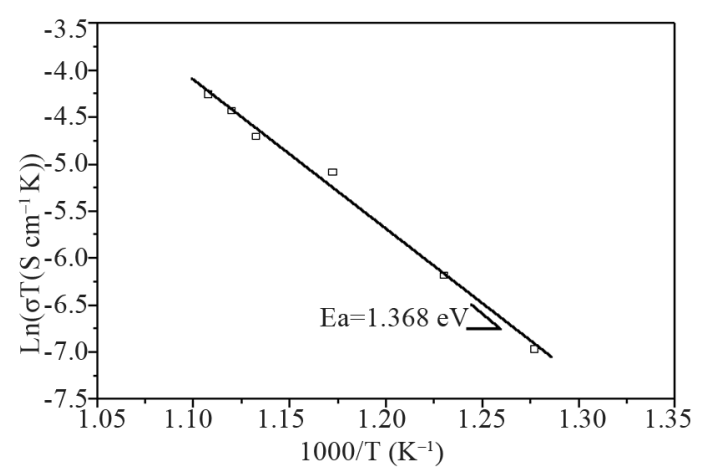

Figure 8. Conductivity Arrhenius plots of $\left(\mathrm{Na}_{0.71} \mathbf{A g}_{0.29}\right)_{2}$ $\mathrm{CoP}_{2} \mathrm{O}_{7}$ sample. 


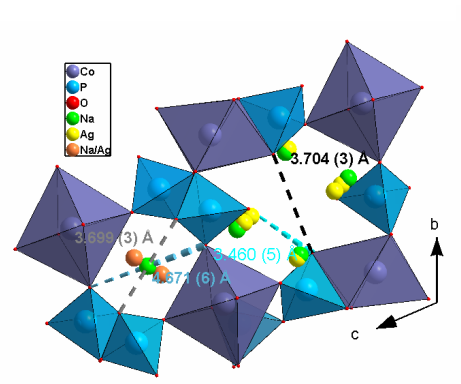

(a)

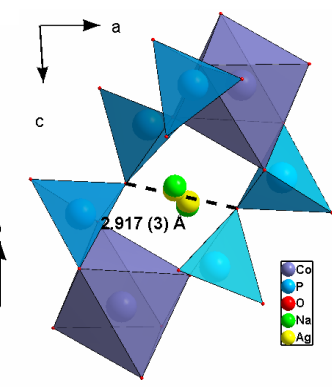

(b)
Figure 9. Dimensions of the tunnel sections in $\left(\mathrm{Na}_{0.71} \mathrm{Ag}_{0.29}\right)_{2} \mathrm{CoP}_{2} \mathrm{O}_{7}$ structure.

and the unit cell parameters are $\mathrm{a}=6.4170(3) \AA, \mathrm{b}=$ 9.4510 (2) $\AA, \mathrm{c}=10.9350(3) \AA, \alpha=115.240(2)^{\circ}, \beta=$ $80.190(3)^{\circ}$ and $\gamma=106.810(2)^{\circ}$. The structure of this material has an open framework having different intercomnecting tunnels running along [100] and [010] where the $\mathrm{Na}^{+}$and $\mathrm{Ag}^{+}$ions are located. The electrical properties of the title compound are investigated using complex impedance spectroscopy. Impedance measurements (frequency/temperature ranges $13 \mathrm{MHz}-5 \mathrm{~Hz} / 783$ - $903 \mathrm{~K}$ ) show $\left(\mathrm{Na}_{0.71} \mathrm{Ag}_{0.29}\right)_{2} \mathrm{CoP}_{2} \mathrm{O}_{7}$ a low electrical conductor being the conductivity $2.61 \times 10^{-7} \mathrm{~S} \cdot \mathrm{cm}^{-1}$ at $683 \mathrm{~K}$ and the activation energy is $1.368 \mathrm{eV}$.

\section{REFERENCES}

[1] B. Aurivillius, C. I. Lindblom and P. Stenson, "The Crystal Structure of $\mathrm{Bi}_{2} \mathrm{GeO}_{5}$," Acta Chemica Scandinavica, Vol. 18, No. 6, 1964, pp. 1555-1557. doi:10.3891/acta.chem.scand.18-1555

[2] M. Nagpure, K. N. Shinde, V. Kumar, O. M. Ntwaeaborwa, S. J. Dhoble and H. C. Swart, "Combustion Synthesis and Luminescence Investigation of $\mathrm{Na}_{3} \mathrm{Al}_{2}\left(\mathrm{PO}_{4}\right)_{3}$ : $\mathrm{RE}\left(\mathrm{RE}=\mathrm{Ce}^{3+}, \mathrm{Eu}^{3+}\right.$ and $\mathrm{Mn}^{2+}$ ) Phosphor," Journal of Alloys and Compounds, Vol. 492, No. 1-2, 2010, pp. 384-388. doi:10.1016/j.jallcom.2009.11.110

[3] K. V. R. Prasad and K. B. R. Varma, "Dielectric and Domain Structural Properties of $\mathrm{Bi}_{2} \mathrm{Ge}_{x} \mathrm{~V}_{1-x} \mathrm{O}_{5.5-x / 2}$ Single Crystals," Ferroelectrics, Vol. 158, No. 1, 1994, pp. 205210. doi:00150199408216017

[4] J. G. Chen, L. Ang, C. Wang and Y. Wei, "Sol-Gel Preparation and Electrochemical Properties of

$\mathrm{Na}_{3} \mathrm{~V}_{2}\left(\mathrm{PO}_{4}\right)_{2} \mathrm{~F}_{3} / \mathrm{C}$ Composite Cathode Material for Lithium Ion Batteries," Journal of Alloys and Compounds, Vol. 478, No. 1-2, 2009, pp. 604-607. doi:10.1016/j.jallcom.2008.11.147

[5] S. Tomohiro, H. Mikio and K. Kohei, "Preparation of Thin Nd-Doped $\mathrm{YVO}_{4}$ Single Crystal Rods by the Floating Zone Method," Materials Research Bulletin, Vol. 35, No. 2, 2000, pp. 225-232. doi:10.1016/S0025-5408(00)00198-7

[6] S. Tomohiro, H. Mikio, K. Kohei, O. Takayo, S. Wada and M. Hiroshi, "Float Zone Growth and Laser Performance of $\mathrm{Nd}: \mathrm{GdVO}_{4}$ Single Crystals," Journal of Crystal
Growth, Vol. 241, No. 1-2, 2002, pp. 159-164. doi:10.1016/S0022-0248(02)01138-7

[7] T. Kanazawa, "Inorganic Phosphate Materials, Materials Science Monographs," Elsevier, Amsterdam, 1989.

[8] F. Sanz, C. Parada, J. M. Rojo, C. Ruiz-Valero and R. Saez-Puche, "Studies on Tetragonal $\mathrm{Na}_{2} \mathrm{CoP}_{2} \mathrm{O}_{7}$, a Novel Ionic Conductor," Journal of Solids State Chemistry, Vol. 145, No. 2, 1999, pp. 604-611. doi:10.1006/jssc. 1999.8249

[9] H. Bih, I. Saadoun and M. Mansori, "The Lamellar $\mathrm{Na}_{2} \mathrm{CoP}_{2} \mathrm{O}_{7}$ Pyrophosphate: Preparation, Structural and Spectroscopic Studies," Maroccan Journal of Condensed Mater, Vol. 7, No. 1, 2006, pp. 74-76.

[10] H. Mahamoud, B. Louati, F. Hlel and K. Guidara, "Impedance and Modulus Analysis of the $\left(\mathrm{Na}_{0.6} \mathrm{Ag}_{0.4}\right)_{2} \mathrm{PbP}_{2} \mathrm{O}_{7}$ Compound," Journal of Alloys and Compounds, Vol. 509, No. 20, 2011, pp. 6083-6089. doi:10.1016/j.jallcom.2011.03.027

[11] N. Dridi, A. Boukhari, J. M. Réau, E. Arbib and E. M. Holt, "Crystal Structure and Ionic Conductivity of Crystalline and Glassy $\mathrm{Na}_{2} \mathrm{PbP}_{2} \mathrm{O}_{7}$," Solid State Ionics, Vol. 127, No. 1-2, 2000, pp. 141-149. doi:10.1016/S0167-2738(99)00277-5

[12] B. Louati, F. Hlel and K. Guidara, "Ac Electrical Properties and Dielectric Relaxation of the New Mixed Crystal $\left(\mathrm{Na}_{0.8} \mathrm{Ag}_{0.2}\right)_{2} \mathrm{PbP}_{2} \mathrm{O}_{7}$, , Journal of Alloys and Compounds, Vol. 486, No. 1-2, 2009, pp. 299-303. doi:10.1016/j.jallcom.2009.06.148

[13] G. M. Sheldrick, "SHELXS-97-A Program for Crystal Structure Determination," University of Gôttingen, Germany, 1997.

[14] G. M. Sheldrick, "SHELXS-97-A Program for Crystal Structure Determination," University of Gôttingen, Gôttingen, 1997.

[15] K. Brandenburg and M. Berndt, "Diamond Version 2.1. Crystal Impact," Bonn, 2001.

[16] F. Hanic and Z. Zak, "The Crystal Structure of $\mathrm{Na}_{7} \mathrm{Mg}_{4.5}\left(\mathrm{P}_{2} \mathrm{O}_{7}\right)_{4}$," Journal of Solids State Chemistry, Vol. 10, No. 1, 1974, pp. 12-19. doi:10.1016/0022-4596(74)90003-6

[17] E. Fatima, A. Bukhari, B. Elouadi and E. M. Holt, "Crystal Structures of Two Allotropic Forms of $\mathrm{Na}_{2} \mathrm{CoP}_{2} \mathrm{O}_{7}$,", Journal of Crystallographic and Spectroscopic Research, Vol. 21, No. 3, 1991, pp. 321-326. doi:10.1007/BF01156084

[18] J. Angenault, J. C. Weaver, M. Quarton and F. Robert, "Structure of $\mathrm{Na}_{3.12} \mathrm{Fe}_{2.44}\left(\mathrm{P}_{2} \mathrm{O}_{7}\right)_{2}$," European Journal of Solid State and Inorganic Chemistry, Vol. 32, No. 1, 1995, pp. 335-343.

[19] F. Erragh, A. Bukhari, F. Abraham and B. Elouadi, "Study of the Crystal Structures of Sodium Magnesium and Sodium Nickel Diphosphates," Journal of Solids State Chemistry, Vol. 152, No. 2, 2000, pp. 323-331. doi:10.1006/jssc.2000.8651

[20] I. D. Brown and C. Calvo, "The Crystal Chemistry of Large Cation Dichromates, Pyrophosphates, and Related Compounds with Stoichiometry $\mathrm{X}_{2} \mathrm{Y}_{2} \mathrm{O}_{7}$," Journal of Solids State Chemistry, Vol. 1, No. 2, 1970, pp. 173-179. 
doi:10.1016/0022-4596(70)90010-1

[21] D. Johnson, "Zview Version 3.1c," Scribner Associates Inc., 1990-2007.

[22] A. K. Jonscher, "The Interpretation of Non-Ideal Dielectric Admittance and Impedance Diagrams," Physica Status Solidi (a), Vol. 32, No. 2, 1975, pp. 665-676. doi:10.1002/pssa.2210320241

[23] A. Ben Rhaiem, F. Hlel, K. Guidara and M. Gargouri, "Electrical Conductivity and Dielectric Analysis of Ag$\mathrm{NaZnP}_{2} \mathrm{O}_{7}$ Compound," Journal of Alloys and Compounds, Vol. 485, No. 1-2, 2009, pp. 718-723. doi:10.1016/j.jallcom.2009.06.062

[24] N. Dridi, A. Boukhari, J. M. Réau, E. Arbib and E. M. Holt, "Crystal Structure and Ionic Conductivity of Crys- talline and Glassy $\mathrm{Na}_{2} \mathrm{PbP}_{2} \mathrm{O}_{7}$," Solid State Ionics, Vol. 127, No. 1-2, 2000, pp. 141-149. doi:10.1016/S0167-2738(99)00277-5

[25] N. Dridi, A. Boukhari, J. M. Réau, E. Arbib and E. M. Holt, "Structure and Electrical Properties of Crystalline and Glassy $\mathrm{Ag}_{2} \mathrm{PbP}_{2} \mathrm{O}_{7}$," Materials Letters, Vol. 47, No. 4-5, 2001, pp. 212-218. doi:10.1016/S0167-577X(00)00237-8

[26] R. D. Shannon, "Revised Effective Ionic Radii and Systematic Studies of Interatomic Distances in Halides and Chalcogenides," Acta Crystallographica A, Vol. 32, 1976, No. 1, pp. 751-764. doi:10.1107/S056773947600155 